\title{
An Economic Analysis of Cattle Marketing in Beed District of Maharashtra
}

\author{
V. S. Thombre, R.D. Shelke* and A.S. Rahane \\ Department of Agricultural Economics, College of Agriculture, Latur, India \\ *Corresponding author
}

\begin{tabular}{l} 
Ke y w o r d s \\
$\begin{array}{l}\text { Cattle, Marketing } \\
\text { cost and Price } \\
\text { spread }\end{array}$ \\
\hline Article Info \\
\hline $\begin{array}{l}\text { Accepted: } \\
\text { 20 October 2020 } \\
\text { Available Online: } \\
10 \text { November } 2020\end{array}$ \\
\hline
\end{tabular}

\section{A B S T R A C T}

Cattle market play an important role in connecting sellers and Buyers and an efficient market is essential to promote the growth. Multistage sampling design was adopted to study the economic analysis of cattle marketing in Beed district of Maharashtra. The study sample comprised of 2 cattle market. 15 sellers, 15 buyers and 15 brokers from each market were selected randomly. Study revealed that, in the total marketing cost, preparation cost accounted to be the highest in case of Buffalo followed by Bullock and Cow respectively. The transportation cost was more or less same of all categories of animals. Brokerage charge also paid both the Buyer and Seller. The cattle owner's share in general varied from 86 to 91 $\%$ to the total price paid by the Buyer. The maximum share $(90.52 \%)$ in case of Bullock and minimum share $(87.70 \%)$ in case of Cow. On an average percentage share of intermediaries in the Buyer's price was 11.18 $\%$.

\section{Introduction}

Livestock sector includes animal husbandry, dairy and fisheries sector are considerable major sector. It plays an important role in National economy and social economic development of the country. It also plays important role in the rural economy as supplementing family incomes and generating gainful employment in the rural sector. Indian livestock industry makes up for a significant amount of world's livestock resources.
India rank first in total milk production. In the year 2018-19 total production of milk in India is 187.7 million tonnes, which was 22 per cent of that year's global total milk production of 843 million tonnes. Due to their high production per capita availability of milk in India is 394 (gms/ day). India's biggest milk producing states are Uttar Pradesh then Rajasthan, Andhra Pradesh and Gujarat state respectively. Maharashtra state ranks $7^{\text {th }}$ in total production of India. Total production of milk in Maharashtra state is $11.10 \mathrm{MT}$. 
Source: (Basic Animal Husbandry Statistics, DAHD \& F, GoI).

The main objectives of this study include to estimate the price spread in the cattle marketing.

\section{Materials and Methods}

\section{Selection of market}

Beed district was selected purposively, because maximum animals of livestocks in Beed district market as compared to other district market. Beed district cattle market is the gateway to the Marathwada, where marketing of various types of animals take place.

\section{Selection of cattle market}

Ambajogai cattle market and salegaon cattle market was selected

\section{Sampling design}

Multistage sampling design was adopted in selection of district, taluka and villages on the basis of highest cattle population.

\section{Selection of district}

At first stage, the Beed district was purposively selected.

\section{Selection of talukas}

Two talukas viz. Ambajogai and Kaij (Salegaon) was selected on the basis of highest cattle population.

\section{Selection of villages}

From each taluka three villages viz. Undri, Esthal, Bansarola, Mudegaon, Dethna and Nandgaon was selected randomly. Thus, in all 6 villages from the two talukas will be selected.

\section{Selection of buyer, seller and middleman}

5 buyer, 5 seller, 5 middlemen will be selected from each village.

\section{Results and Discussion}

\section{Cost of marketing and price spread}

In cattle market, cost of marketing includes following services these are cost of preparation of animal for sale, transportation charges, and brokerage charges. Marketing cost is generally measured by the difference of prices received by its producers. Middleman play important role in cattle marketing due to the cost of marketing help to knowing the intermediary agencies interve between the producer and consumer. Details of the study of cot cattle marketing may help to suggest the way and means of reducing the same.

\section{Preparation of animal for sale}

For getting better price in the market many sellers prepare the animal for sale that include washing the animal, grooming, coloring, decorticating the horns. Shaving for the buffalo but in some cases some of the owner do not take very little or no attention in all respects cost of preparation of animal is negligible.

\section{Distribution of cost amount different Agencies}

In village level some of the owner they can sell cattle at village / or on the farm that "way cost of distribution is nil. Due to this owner share in the price paid by the buyer is $100 \%$. In case of long distance from farm to cattle market various additional charges are required these are
a) Transport charges
b) Market charges
c) Feeding charges 
These charges are required to be paid both by the sellers and buyer. This information can collate form selected seller and buyer of different of animals. On the basis of data, per animal marketing cost has been incurred by seller and buyer on the above-mentioned cost items.

Table 1 shows that cost incurred on the preparation of animals for market was more or less same. It was $2.18,2.09$, and 2.87 per cent of total cost of bullock, cow and Buffalo respectively. In case of buffalo $2.87 \%$ of total cost for preparation for sale this is high as compared to bullock and cow. This is because the buffaloes are prepared for sale by washing, oil massage, shaving etc. feeding cost incurred by seller for bullock, cow, and buffalo was $2.90,3.14$, and $3.23 \%$ of the seller total cost respectively. Table 1 shows that feeding cost of the buffalo was comparatively high than another animal.

In total marketing cost transportation cost is major cost of the cattle marketing. Near about transportation cost was more or less same for all animals. Variation in the transportation cost occurred because distance to be covered from seller home to market place to the home of the buyer and time required to cover this distance.

Notable difference found in marketing fees. Market fees paid by the buyer and seller separately in case of all animals. This difference due to the seller has to pay only admission fee whereas the buyer has to pay all remaining charges that include attestation fees, market fees, supervision charges etc.

\section{Transportation cost}

Transportation cost is major cost in total marketing cost. Transportation cost depends upon the distance. From seller village to the market. And market to the buyer village. Animal's rearers are mainly from the distant places, so they bring their animals for selling through trucks, tempos or any other vehicle etc.

\section{Feeding cost}

Feeding cost include charges paid by the feeding and watering of the animal. Feeding cost of the seller start from the time they leave their village and ends after the animal handed over to the buyer. And feeding cost of buyer start from the time of taking the animals into possession till it reaches to his home.

\section{Marketing charges}

Market committee fixed marketing charges. Marketing charges paid to both buyer and seller. Admission fee is pay by the seller. And attestation fee which varies according to the sale value of the animal

\section{Brokerage}

Broker play important role in cattle market brokerage charge depends upon the price of that animal. And broker gives charge from both seller and buyer. Sale value of the animal to be paid by both buyer and seller separately. As transportation cost brokerage charge are near about same this is about brokerage.

\section{Price spread of different animals}

Due to the price spread it is important to knowing about the exact income or benefit received by the market intermediaries as well as producer / seller to the price received from final buyer form the following table 2 it is to be clear that cattle owners share in general varied from 87.70 to $90.52 \%$ maximum share in case of bullock and minimum share in case of cow. 
Table.1 Details of cost of marketing for different types of animal

\begin{tabular}{|c|c|c|c|c|c|c|c|}
\hline \multirow[t]{4}{*}{ Sr. no } & \multirow[t]{4}{*}{ Particulars } & \multicolumn{6}{|c|}{ Kinds of Animal } \\
\hline & & \multirow{2}{*}{\multicolumn{2}{|c|}{$\begin{array}{l}\text { Bullocks } \\
\text { Cost navable bv }\end{array}$}} & \multicolumn{2}{|c|}{ Cow } & \multicolumn{2}{|c|}{ Buffalo } \\
\hline & & & & \multicolumn{2}{|c|}{ Cost payable by } & \multicolumn{2}{|c|}{ Cost payable by } \\
\hline & & Seller & Buyer & Seller & buyer & Seller & buyer \\
\hline 1 & $\begin{array}{l}\text { Negotiated } \\
\text { price of } \\
\text { animal }\end{array}$ & 25511 & 25511 & 12800 & 12800 & 20000 & 20000 \\
\hline 2 & \multicolumn{7}{|c|}{ Marketing cost } \\
\hline a) & $\begin{array}{l}\text { Preparation } \\
\text { for sale }\end{array}$ & $\begin{array}{l}30.00 \\
(2.18)\end{array}$ & - & $\begin{array}{l}20.00 \\
(2.09)\end{array}$ & - & $\begin{array}{l}40.00 \\
(2.87)\end{array}$ & - \\
\hline b) & Feeding cost & $\begin{array}{l}40.00 \\
(2.90)\end{array}$ & $30(2.60)$ & $\begin{array}{l}30.00 \\
(3.14)\end{array}$ & $\begin{array}{l}20.00 \\
(2.83)\end{array}$ & $\begin{array}{l}45.00 \\
(3.23)\end{array}$ & $\begin{array}{l}25.00 \\
(2.28)\end{array}$ \\
\hline c) & $\begin{array}{l}\text { Transportation } \\
\text { cost }\end{array}$ & $\begin{array}{l}800.00 \\
(58.18)\end{array}$ & $\begin{array}{c}600 \\
(52.17)\end{array}$ & $\begin{array}{c}500 \\
(52.35)\end{array}$ & $\begin{array}{c}300 \\
(42.55)\end{array}$ & $\begin{array}{c}800 \\
(57.55)\end{array}$ & $\begin{array}{c}500 \\
(45.66)\end{array}$ \\
\hline d) & $\begin{array}{l}\text { Marketing } \\
\text { fees }\end{array}$ & $\begin{array}{c}5.00 \\
(0.36)\end{array}$ & $70(6.08)$ & $\begin{array}{c}5.00 \\
(0.52)\end{array}$ & $\begin{array}{c}85.00 \\
(12.05)\end{array}$ & $\begin{array}{c}5.00 \\
(0.35)\end{array}$ & $\begin{array}{l}70.00 \\
(6.39)\end{array}$ \\
\hline e) & Brokerage & $\begin{array}{l}500.00 \\
(36.36)\end{array}$ & $\begin{array}{c}450 \\
(39.13)\end{array}$ & $\begin{array}{c}400 \\
(41.88)\end{array}$ & $\begin{array}{c}300 \\
(42.55)\end{array}$ & $\begin{array}{c}500 \\
(35.97)\end{array}$ & $\begin{array}{c}500 \\
(45.66)\end{array}$ \\
\hline f) & Total cost & 1375 & 1150 & 955 & 705 & 1390 & 1095 \\
\hline 3) & $\begin{array}{l}\text { Sellers or } \\
\text { buyer actual } \\
\text { price }\end{array}$ & 24136 & 26661 & 11845 & 13505 & 18610 & 21095 \\
\hline
\end{tabular}

Table.2 Price spread of different kinds of animal

\begin{tabular}{|c|c|c|c|c|}
\hline \multirow{2}{*}{ Sr. No } & Particulars & \multicolumn{3}{|c|}{ Kind of Animals } \\
\cline { 3 - 5 } & & Bullock & Cow & Buffalo \\
\hline $\mathbf{1 )}$ & Total price paid by the buyer & 26661 & 13505 & 21095 \\
& & $(100)$ & $(100)$ & $(100)$ \\
\hline $\mathbf{2 )}$ & Cost Incurred by buyer & 1150 & 705 & 1095 \\
& & $(4.31)$ & $(5.22)$ & $(5.19)$ \\
\hline $\mathbf{3 )}$ & Net price paid to seller & 25511 & 12800 & 2000 \\
& & $(95.68)$ & $(94.77)$ & $(94.80)$ \\
\hline $\mathbf{4 )}$ & Cost incurred by seller & 1375 & 955 & 1390 \\
& & $(5.16)$ & $(7.07)$ & $(6.5)$ \\
\hline $\mathbf{5 )}$ & Net price received by seller & 24136 & 11845 & 18610 \\
& & $(90.52)$ & $(87.70)$ & $(88.21)$ \\
\hline $\mathbf{6 )}$ & Total intermediary charges & 2525 & 1660 & 2485 \\
& & $(9.47)$ & $(12.29)$ & $(11.78)$ \\
\hline
\end{tabular}

This variation is due to the different in price fetched by the respective animal in the market form the percentage of cost incurred by the seller have to spend proportional more than buyer in the marketing of animals. The reason is buyer are not required to spend any thing 
on items as like preparation of animals and at time on transportation also.

In case of percentage total intermediary charges paid both buyer and seller varies from 9.47 to $12.29 \%$ showing there more contribution in the buyer price.

Hence concluded, in the total marketing cost, preparation cost accounted to be the highest in case of Buffalo followed by Bullock and Cow respectively. The transportation cost was more or less same of all categories of animals. Brokerage charge also paid both the Buyer and Seller. The cattle owner's share in general varied from 86 to $91 \%$ to the total price paid by the Buyer. The maximum share $(90.52 \%)$ in case of Bullock and minimum share $(87.70 \%)$ in case of Cow. On an average percentage share of intermediaries in the Buyer's price was $11.18 \%$.

\section{References}

Bankar S.S., Pawar B.R., and Kakade A.D. (2010) Marketed surplus and price spread in marketing channels of buffalo milk. International journal of commerce and business management3 (2): 206208.

Arficho M. T. (2011) Price spread analysis of cattle in hadiya pastoral areas. Journal of Biology, Agriculture and Healthcare 1 (1): 59-70.

Das, G., Jain, D.K. and Dhaka, J.P. (2014) Analysis of price spread and marketing efficiency of milch cow marketing in the state level cattle fairs of Rajasthan, India. Indian journal of Agri.Econ, 12(1):33-47.

Singh O.N. and Dubey A.K. (2016) Price spread and marketing efficiency of buffalo owners in different Milk marketing channels in Allahabad District. International Journal of Applied and Pure Science and Agriculture 2 (09): 54-59.

\section{How to cite this article:}

Thombre, V.S., R.D. Shelke and Rahane, A.S. 2020. An Economic Analysis of Cattle Marketing in Beed District of Maharashtra. Int.J.Curr.Microbiol.App.Sci. 9(11): 2916-2920. doi: https://doi.org/10.20546/ijcmas.2020.911.354 